\title{
Financially resourcing the ministry in the Uniting Presbyterian Church in Southern Africa in the 21st century
}

\author{
Author: \\ (Arthur) Roger Tucker \\ Affiliation: \\ Department of Practical \\ Theology, University of the \\ Free State, South Africa \\ Correspondence to: \\ Roger Tucker \\ Email: \\ rogertucker@mweb.co.za \\ Postal address \\ PO Box 28296, Danhof 9310, \\ South Africa \\ Dates: \\ Received: 09 Nov. 2011 \\ Accepted: 10 Sept. 2012 \\ Published: 13 Nov. 2012 \\ How to cite this article: \\ Tucker, A.R., 2012, \\ 'Financially resourcing the \\ ministry in the Uniting \\ Presbyterian Church in \\ Southern Africa in the 21st \\ century', Verbum et Ecclesia, \\ 33(1), Art. \#695, 12 pages. \\ http://dx.doi.org/10.4102/ \\ ve.v33i1.695
}

C 2012. The Authors

Licensee: AOSIS

OpenJournals. This work

is licensed under the

Creative Commons

Attribution License.
From 1994 the Uniting Presbyterian Church in Southern Africa has increasingly encountered tremendous challenges in financing its ministry on a just and equitable basis across all communities. This issue peaked when the Presbyterian Church of South Africa and the Reformed Presbyterian Church united to form the Uniting Presbyterian Church in Southern Africa (UPCSA) in 1999. The union produced tensions concerning the financial support of the ministry. These centred on as yet unresolved proposals for the centralisation and equalisation of ministerial stipends, which have been discussed at every biennial General Assembly of the UPCSA from 2006. This article has briefly analysed the theological, ecclesiological, missional, economic, sociological and practical administrative issues that it believes should inform the final decision and may help to establish a new ministerial, missional and congregational support paradigm for many other churches in the new South Africa.

\section{Introduction}

\section{Historical background}

A common term used in this article, and which describes the arguments which it focuses on, is the word, 'stipend'. The Dictionary of Scottish Church History and Theology defines it as, 'the living allowance received by the full-time minister in most Churches' (Herron 1993:797, 798). The Scottish source of this definition is pertinent because both reformed denominations that now form the UPCSA (Uniting Presbyterian Church in Southern Africa) owe their origins to the Church of Scotland.

The UPCSA was formed and constituted in 1999 as the outcome of the union between the Reformed Presbyterian Church in Southern Africa (RPCSA) and the Presbyterian Church of Southern Africa (PCSA). The two churches had very different backgrounds. The Presbyterian Church in Southern Africa was first constituted amongst soldiers and settlers, mainly of Scottish origin, who arrived at the Cape in 1820 and became essentially a privileged 'settler' church, although it subsequently planted congregations amongst the indigenous and disadvantaged communities.

The Reformed Presbyterian Church (RPC), on the other hand, was a product of a mission originating from the Free Church of Scotland intended for the indigenous population. It started at Lovedale Mission in Alice. In 1900 the Free Church had entered into a union with the United Presbyterian Church (UPC) and adopted their stipendiary structure, which was voluntarist and largely congregational (Sawkins \& Mochrie 2009:22).

In 1923, the RPC was constituted an autonomous indigenous denomination, being initially called the Bantu Presbyterian Church of South Africa. The UPC pattern was followed in that the voluntarist and congregational stipendiary structure was adopted at the 1924 General Assembly (BPCSA G.A. Minutes 1925:66).

It appears that because of pressure caused by the seizure of property and forced removals by the Nationalist government the system was changed in the late 1970s. Unfortunately, no easily available explicit documents exist which record the adoption of the change or its details (personal communication from Rev. Dr Graham Duncan, Professor of Church History at Pretoria University). The process is only hinted at in the minutes of the 1980 General Assembly, which state, 'That the General Assembly approves the rationalization and re-allocation of assets and existing funds' (RPCSA 1980:30). A centralised stipend payment system was then adopted which was retained until union with the PCSA (UPCSA 2010:199). The amount each minister received depended upon years of service. 
When union took place in 1999, the RPC agreed to the traditional PCSA method of paying ministerial stipends. This was a voluntarist and congregational stipendiary structure in which each local congregation was responsible for financially supporting the minister who served it. Those congregations who found it impossible to meet the minimum stipend applied for assistance from a centralised fund, which could, and often did, provide the necessary financial support to enable this.

\section{Some issues informing the debate}

The union extended the congregational base of the new denomination across a much more representative economic cross-section of South Africa than either had ministered to before. As a result it has produced new and heightened expectations and tensions concerning the financial support of the ministry. One source of tension is that the expectations from some of those ministering in previously disadvantaged communities have not been fulfilled. Those ministering in the more affluent congregations still often receive a greater income than those in the poorer congregations, which, to judge from the General Assembly debates, is perceived by a large minority cross-section of denominational members as unjust. They also believe that the church has a moral obligation to come to a more equitable stipendiary system (UPCSA 2010:463). It must be added that similar stipendiary discrepancies existed in the RPCSA prior to union, but these were not perceived as racially based.

At the time, as always in South Africa, a sense of the factual historical injustices and inequities of apartheid appeared to be colouring the debate. This is very pertinent to the situation in South Africa in 2011. South Africa's liberation movement achieved only political freedom in 1994, and not what was considered economic freedom. The greatest challenge for all South Africans lies in the apposite resolution of the problem of poverty and the process of transformation. Dames (2010) says:

White communities benefited from the liberation movements' political achievements through retaining key economic power and demographic privileges. Moreover new guises of economic superiority and the perpetuation of old imbalances are prevalent today. (p. 2)

\section{Reason for the article}

The issues facing the UPCSA are certainly not unique to that denomination in South Africa or to any multi-cultural Christian organisation in the developing world. They will probably be faced sooner or later by its sister Reformed and Presbyterian Churches and maybe in other church families outside of that tradition, in developing countries. It is thus hoped that some of the arguments and ideas expressed in this article will be helpful to them as they seek to resolve a complex matter.

\section{Proposal for centralisation at 2010 General Assembly}

These arguments were highlighted at the 2010 General Assembly when the Maintenance of the Ministry Committee of General Assembly submitted a proposal stating that:
- Every congregation in South Africa which has a minister, called or appointed, will pay to the Presbytery (or Synod) the full cash stipend of their minister(s) (less grant in aid of stipend where relevant) by the 15th day of every month.

- Presbyteries in South Africa shall remit to the UPCSA Assembly Office their entire stipend bill together with contributions for pension, long leave and medical aid subscriptions (where relevant) for every minister called or appointed by the 20th day of every month.

- The Assembly Office shall deduct tax and other statutory deductions and pay this to the South African Revenue Service. Every minister in South Africa shall receive on the 25th day of every month from the Assembly office a stipend equal to the Presbytery's minimum stipend less relevant deductions if the congregation has remitted the due amount (UPCSA 2010:199ff).

As the committee admits:

(it) has spent the last 11 months considering the possibility of a Centralised Stipend system. The committee is aware that the system suggested constitutes a massive change to the way ministers are currently paid but would like to point out that a Central Stipend payment system existed in the former RPC before union. The committee would also like to state that the system suggested is a first step toward the hope of an equalized UPCSA stipend. (ibid:199 [italics author's own])

It suggested that:

This system will be implemented as a pilot project for two years, during which the committee will evaluate it and suggest changes to the Assembly or Executive Commission. We estimate a total set up cost of about R30 000 and a monthly cost (for employees) of about R20 000 to R30 000. (ibid 200)

After discussion, the General Assembly agreed to the following resolution:

The Assembly refers the proposal back to the Maintenance of the Ministry committee for further research and report on the implementation of the Centralization of stipend system and instructs it to give a detailed report to the 2011 Executive Commission. (UPCSA 2010:376)

\section{An ongoing debate?}

On receipt of the report from the Maintenance of the Ministry Committee, the Executive Commission decided not to implement the centralisation system (UPCSA 2011:34).

The reasons for the rejection of the proposal were not stated. Despite the Executive Commission's decision, it seems unlikely that this is the end of the debate. The issues driving the proposal and polarising the denomination are too deep. As a result, the circumstances causing ministers to want centralisation and thereafter equalisation will not go away in the foreseeable future.

Thus, it seems appropriate at this stage of the debate to take a fresh look at the entire issue from theological and contextual viewpoints. Some people feel that the debate has been going on for too long. However, despite much thought given to the issue by the committees concerned, it appears to the author that no biblical and theological basis has ever been presented as a foundation from which to make informed decisions. 
If a theology has been developed it has not been published in any General Assembly paper. Many years ago Zerfass (1974:167ff) proposed that for a church to make decisions that would be effective and appropriate in today's world they must be informed by, not only, contextual and pragmatic factors, but under the influence of a biblical and theological hermeneutic, taking tradition into account. This would appear to be an essential first step for any Reformed Church, which prides itself on its tradition of well thought-out biblical scholarship (Leith 1992:5ff.). Thus theology, social justice, ecclesiology, missional growth, congregational autonomy, financial viability and practical administration must all inform the debate.

\section{Theological issues \\ A theology of stewardship}

The area of theology that would be most pertinent to this debate would seem to come under the heading of 'stewardship'. Stewardship may simply be defined as the theology of managing, on God's behalf, all that he has given humankind authority over. This includes the resourcing and method of stipendiary payments within a congregation or denomination. The stewardship concept is perhaps most explicitly expressed in the New Testament in the parable of

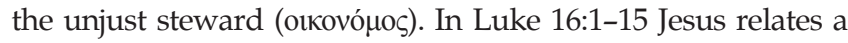
parable where a steward is entrusted with extensive financial responsibility and freedom and is able to spend and make financial transactions in his master's name. This emphasises the point of the entire unit (Lk 16:1-31), namely, that, 'both allegiance to the law of God and response to the proclamation of God find their proper reflection in the handling of wealth' (Nolland 1993:795). Thus, the biblical doctrine of the handling of money is often called 'stewardship'.

This concept goes back to Genesis 1:26-27 which reveals a God who has created a world external to his being and then men and women in his image (imago Dei). The imago Dei indicates that humankind mediates within creation the immanence of the transcendent Creator (Grenz 2005:88).

\section{Humankind was created by God to be his stewards}

Thus, in Genesis 1:28 God places men and women in the world giving them authority over it to manage it in his place, representing the One in whose image they were made, 'Rule over the fish of the sea and the birds of the air and over every living creature that moves on the ground'. The witness of the Old Testament is, 'Yahweh's capacity to govern and order in ways that assert sovereign authority and that assure a coherent ordering of life in the world' (Brueggemann 1997:233). He is the ultimate manager, although not a subordinate one. Men and women made in his image thus have the ontological capacity to manage, the difference being that they are subordinate and do not own what they manage. They are thus 'stewards' in the full meaning of the word, which is somebody who serves another.

As McGrath (2007:230) comments, 'Domination in Genesis 1:26, 27, can be understood specifically in terms of stewardship'. Whilst McGrath is referring to an ecological stewardship, the concept can be extrapolated to a fiscal stewardship. Both nature and our financial resources are gifts from God that he intends to be managed faithfully and well.

\section{Faithful stewardship produces abundance}

God intends and has equipped men and women to manage his world in order to produce an abundance so as to sustain themselves.

\section{According to Venter (2011):}

The theological work of the past few decades helps us to understand that the divine relationships (within the Trinity) ... should be described in terms of fecundity ... hospitality, generosity ... (p. 9)

In the biblical salvation narrative we read once more of the fecundity of the Father, the unselfish emptying of the Son (kenosis) and the freedom of the Spirit revealing the love, abundance, self-giving and generosity of the Trinity in whose image men and women are made. Genesis 1:28 says: 'Be fruitful and increase in number; fill the earth and subdue it'. This emphasises that stewards created in the image of God are to manage God's world to produce an abundance that will sustain them and enable them to be fruitful and multiply (Corbett \& Fikkert 2009:58).

In order to produce these results we need a society and a church (as the Master's servants) that exercise stewardship faithfully, wisely and industriously (Mt 25:14-30; Lk 16:116). Such a stewardship includes giving to and empowering the poor, ameliorating social injustice and economic inequity (Lk16:19-31), and the growth of the Kingdom of God through missional outreach by local congregations or ecclesiastical affiliations, and doing so with freedom, abundant generosity and love.

\section{Stewardship that produces abundance is implemented through faithfulness to calling}

Not everybody is given the same stewardship role. Closely connected with the imago Dei and stewardship is the concept of calling. Immediately after God created humankind in his image he called them to rule over the earth as his managers. The precise nature of each person's stewardship role diversified into many different functional roles as society expanded. God supplied differing gifts and talents (as indicated by the parable of the talents in Mt 25:14-30) to fulfil the role each person had been called to. As Calvin (Institutes III) writes:

... the Lord enjoins every one of us, in all the actions of life to have respect to our own calling ... he has assigned distinct duties to each in the different modes of life by the name of callings. (p. X.vi)

Stewardship is fulfilled through the vocation to which each has been called. God calls men and women first of all to be fully human (Vanhoozer 1997:183), to a human way of life (Webster 2003:230ff) and also to such vocations as, 'father, farmer, craftsman, teacher, soldier, judge ...' (Atkinson 1988:711). He has designed us all as unique beings with different gifts, genes, personalities, opportunities, backgrounds and desires in order that society may function as a healthy body. Each 
person has different roles to play according to his or her calling. When God calls, he enables. So Davies and Allison (1997:402) comment on Matthew 25:14-30, 'Christians have received gifts according to their ability and it is how they make use of these gifts that counts'.

These different vocations, locations and aptitudes for work will be rewarded with different remunerations and life-styles, as Jesus' parables concerning stewardship imply. More than that, it would appear to be a logical deduction that it is only when individuals are faithful to their God-given calling that the optimum result of their stewardship is produced, which in turn blesses others with the consequent abundance.

\section{Faithfulness to calling involves a fair wage for a fair day's work}

God is concerned with what men and women do with the gifts, possessions and money that he indirectly gives to them through inheritance, labour, gifts from others, and the way in which it is earned. The employer is not doing the employee a favour when he pays him or her (Rm 4:4). When an employee is not paid the wages he or she derserves, it constitutes theft (Jas 5:4). The Bible instructs that those who hire labour should pay a fair wage $(\mathrm{Gn} 31: 12,13)$ and pay employees at the time agreed upon (Lev 19:13). Moreover, one might say that when labour is hired a covenant is established between employer and employee, which will be transgressed if its terms are not adhered to.

On the other hand once the wage has been agreed on the employee is to be satisfied with it (Lk 3:14) and is encouraged not just to work for their pay, but to have the employee's best interests at heart (Jn 10:13). Following on from this, a worker is to be remunerated in accordance with his or her industry and capability (1 Cor 3:8). This must be taken into consideration by the denomination and the local congregation when a decision is made regarding a fair remuneration for a minister. It also means that when a minister does not receive his or her remuneration at the agreed time, the covenant between the minister and the congregation is being broken and God is being robbed.

This may appear to be contradicted in Matthew 20:1-16 by the fact that the workers in the vineyard all received the same pay no matter how hard or how long they had worked. However, Davies and Allison (1997:67ff) are clear that this parable applies to the last judgement. They give a list of six interpretations of the purpose and meaning of this parable by such scholars as Irenaeus, Calvin and Barth and none of these interpretations speak of employment by earthly employees. Their interpretation is that payment represents the reward which disciples or workers will receive at this judgement and that the parable functions as a warning against boasting from disciples who presumed themselves to be amongst the first.

Admittedly, it is never easy to be precise about the purpose of a parable. But if in any way it does apply to earthly work, a further point that may be reflected on in the parable is that a calling to service is in direct relation to the need, as God decides, and that any earthly reward we are given for this service is his gracious meeting of our needs. These rewards may differ or be the same according to God's sovereign decision. Thus, the employee must seek to avoid falling prey to a work-for-wages spirit with respect to spiritual matters and be careful of envying those who seem to have greater rewards.

The English Standard Version (ESV) Bible comments in a footnote that the workers in the parable failed to be thankful for their own wage because they were blinded by self-interested lack of compassion. Disciples of Jesus should not measure their own worth by comparing it with the accomplishments and sacrifices of others. They should focus on serving from a heart of gratitude in response to God's grace.

\section{Faithfulness to calling means paying off debt}

Debt may be defined as, 'Money or property which one person is obligated to pay to another' (Dayton 1996:35). Getting into debt is not forbidden in the biblical documents, and was even seen as necessary in ancient Israelite agricultural society (Willingale 1982:276). Yet repayment was considered obligatory (Ps 37:21, Rm 13:8). Whatever repayment agreements had been made needed to be fulfilled. If they were not, the resultant indebtedness may even have been considered to be a sign that the debtor was under a curse (Deut 28:44).

Ministers and congregations often incur debt to finance the maintenance and expansion of the missional ministry. In this respect, loans are made from UPCSA central funds to ministers and congregations to cover the costs of transport, remuneration of ministers, for extensive maintenance, extension and erection of buildings.

At the moment there is a large amount of debt owed to the central funds of the UPCSA which is not being repaid. As of 2009, the outstanding loans amounted to approximately R500 000 (UPCSA 2009:16), which is a large sum for a small denomination. Much of this amount dates back several years and is not being repaid. Moreover the debt incurred by some local congregations is increasing all the time because 'there remain many congregations that are not paying assessments' and 'other congregations pay less than they are supposed to pay'. (UPCSA 2006:462). Thus, it was decided to place a moratorium on offering loans until the situation improved (UPCSA 2010:199).

This lack of repayment clearly is contrary to the principles concerning debt reimbursement that are found in scripture, and may have serious spiritual and social repercussions both for ministers and congregations.

\section{Sinful human nature hinders stewardship faithfulness}

Faithful stewardship does not always occur because, as the Bible amply testifies, the reality of our fallen human nature is that we are often lazy, deceitful, selfish, greedy or fearful, especially with regard to finances. Allowing such attitudes to determine our behaviour has serious consequences. If life is 
not received or experienced as a gift from God then, ultimately, contact with reality is severed and futility is the result. The individual's ability to respond effectively to the call of God or fulfil God-given potential is damaged. Choices are driven by reaction to relational, environmental and cultural influences and there is powerlessness to live according to God's values of love, generosity and servanthood. Character does not mature and we are unable to fulfil our God-given role as his stewards. Consequently, the effects of men and women's sin affects the economic, social, political and religious systems humans have created throughout history which in turn sustains poverty, inequity and misery. At a more practical level it affects faithfulness in paying assessments, minister's stipends and the management and repayment of debt.

\section{Faithful stewardship means sharing abundance}

The outcomes that God desires from biblical administration are that the church (as the Master's servant) should exercise stewardship faithfully, wisely and industriously (Mt 25:14-30; Lk 16:1-16). These results would include giving to and empowering the poor, ameliorating social injustice and economic inequity (Lk 16:19-31), and the growth of the Kingdom of God through missional outreach by local congregations or ecclesiastical affiliations, and doing so with freedom, overflowing abundant generosity and love.

It is in God's economy that abundant financial wealth is to be shared with poorer congregations. However, the only example in the New Testament where sharing took place between congregations is the Palestine Relief Fund. It is mentioned in four places in the New Testament: 1 Corinthians 16:1-3; 2 Corinthians 8-9; Romans 15:26; Romans 15:27; Acts 24:17 (Plummer 1915:229, 230). This could mean that the collection for the Jerusalem congregation was an exceptional circumstance where abundance was shared to meet the onceoff needs of the 'mother church'. The members of the mother church in Jerusalem could have been suffering from extreme poverty because of drought, persecution by their employers for their faith and even from the brief failed experiment in which the members of the church all sold their property and put it into a common store (Plummer 1915:382; Dodd 1932:230).

These references reveal several guiding principles concerning such sharing. It was meant to be a reciprocal arrangement depending upon need (2 Cor8:14). Although not explicitly stated, there were to be certain safeguards. Sharing was to be for a particular purpose. It was to be willingly given by the donor congregation (2 Cor 8:3, 4; 9:7; Rm 15:27). The element of 'a semi-legal' levy or debt inferred in Romans 15:27 is interpreted by commentators as being the spiritual debt owed by the Gentiles to the Jews (Morris 1988:52; Fitzmeyer 1993:722; Moo 1996:905; Jewett 2007:930). The donor congregation had the right to expect it to be used responsibly for the purpose for which it was given (2 Cor 8:18-21). For this reason, Paul stipulated that responsible church members should be selected to oversee the handling and delivering of the gift (Martin 1986:257). The main motive for giving was to be gratitude to God for the indescribable, enriching gift of grace and salvation to believers through Jesus (2 Cor 8:9; 9:15).
The benefits of such giving were that the Lord would reward the donor congregation (2 Cor 9:6) so that they would have all the resources they needed to continue being generous to the poor (2 Cor 9:8-12). The amount of spiritual blessing they would receive was proportional to the degree of sacrifice as measured in proportion to their income and not as an absolute value (2 Cor 8:12). The Kingdom of God is strengthened as congregations take responsibility for other congregations. It is a necessity if they are to grow spiritually.

\section{According to Chaffin (n.d.):}

Paul lays down the principle that people who give generously out of love for the Lord and His church grow and mature in their faith because they don't count the cost. (2 Cor 8:1-15)

The receiving congregation then has the responsibility to pray for the donor congregation (2 Cor 9:12-15). Harnack (1908:160, 161) says that, 'This collection formed the one visible expression of that brotherly unity which otherwise was rooted merely in their common faith'.

Thus, when there is a sharing of financial abundance between congregations the entire Kingdom of God is advanced not only because the recipient congregations are resourced, but also the donor congregations grow spiritually through their sacrifice and prayer.

\section{Faithful stewardship needs the Cross}

Thus, faithful stewardship as McLaren (2004:270) writes would realistically take a miracle. Yet this miracle of stewardship that God intended is possible because of the atonement of the Cross. We are only able to be the people God purposed us to be when we become part of a new humanity who share in the divine image of Christ (Grenz 2005:92). Thus, the most important call is to follow Christ, by which we are summoned to an exclusive attachment to his person (Bonhoeffer 1959:49). Without this attachment none of these other calls are possible of fulfilment and true stewardship is also impossible.

Only when we surrender to God is the work of Jesus on the Cross internalised within us. Only then are we given the desire to keep God's precepts and commands and the freedom to obey them, so that we can make the right stewardship choices. Only then can God, the Holy Spirit, empower us to enact these choices. 1 Corinthians 3:18 reveals that change is attained through the continuous perception of Christ (Thrall 1996:286). As believers practice this, they are transformed into his image. This results in an ethical transformation as the Holy Spirit produces a visible Christ-like character. The divine image becomes progressively visible in the believer's behaviour and he or she gradually overcomes laziness, greed, deceitfulness, selfishness and fear.

Then, and only then, 'Can we imagine an economy based on stewardship rather than exclusive ownership' McLaren (2004:270). We then see beyond the individual to the community, beyond selfishness to sharing and beyond personal fulfilment to mission. This may be defined as seeing, 'our participation in God's projects in God's world for God's purposes' (McClaren 2004:270). 


\section{Practical implications of the theology of stewardship}

The centralisation or equalisation debate has to be informed by the concept of responsible sharing, calling and vocation. Congregational ministers will always receive differing rewards for their service depending upon circumstance, ability, work ethic and calling. There will always be some injustices, imagined or real, in this area. The ideological desire for social justice and the Christian desire to be generous must take into account human sinfulness. Whilst wise and industrious administration will help, social justice will only be really ameliorated as congregations and ministers experience the transforming ethical work of the Cross and the Holy Spirit, resulting in attitudinal and behavioural change so that laziness, greed, deceit, selfishness and fear of want are overcome. Thus perhaps, anointed preaching and teaching leading to repentance and behavioural transformation through the power of the Holy Spirit is as vital a first step as any other to resolve this debate.

\section{New Testament ecclesiological tradition}

\section{New Testament practices should be taken into account}

Presbyterians are facing a paradox in the 21st century. It must be admitted that there is no fixed biblical model of the social structure by which the church is to exist in the world. Moreover, the New Testament church was radically different in organisation from the 21st century church, as was the situation in which it operated. Organisationally it was more congregational than many denominations that exist today, such as the UPCSA. It was a new movement which had yet to consolidate its structures and relationships between congregations. Authoritative centralisation and interdependence have developed as a result of the experience of the last 2000 years, and cannot be summarily dismissed as an 'unscriptural' practice. It has significant advantages over the system of independent congregations with only loose organisational ties that characterised the first century church. It is, however, suggested that a mediating position for any Presbyterian Church to take is that, wherever it is applicable in the current contemporary social context, the clear biblical model for any practice should be followed.

\section{Financially autonomous congregations}

The New Testament documents provide evidence that local congregations were normally expected to financially support the full-time church leaders who served them (Mt 10:10; Lk 10:7; 1 Tim 5:17, 18; 1 Cor 9:9, 10). This meant that those in poor communities would probably receive less than those in rich communities. This difference in remuneration might also have been exacerbated because industry and ability were to be rewarded appropriately. In addition, church leaders appear to have differed greatly in industry, diligence, talents, skills, and ability for creative, faith-inspired risk-taking (Mt 25:14-30, 1 Cor 12:28; Eph 4: 11; 1 Pet 4:10) for which they were to be rewarded appropriately $(1 \operatorname{Tim} 5: 17,18)$.
The concept of the equalisation of wages is not found in the Bible. The idea often attributed to Marx, 'From each according to his ability, to each according to his need', is nowhere found within it. The closest the Bible gets to this concept is the 'Jerusalem Experiment' of Acts 2: 44, 45, which appears to have been discontinued within a few years and it is not mentioned again. Nowhere is this upheld as a model to be copied (although generosity is encouraged) and was probably an unsustainable practice, as Paul's need to collect money for the Jerusalem church seems to indicate (1 Cor 16:1-3).

\section{Inevitable jealousy}

Differences in financial remuneration would open the way for more poorly paid church leaders to be jealous of those who were better off. In a perfect world this should not have become an issue because many of the factors contributing to an appointment depended upon God's particular calling for the leader, including location for ministry. However, in the fallen world in which we live it was only to be expected that it may have become an issue. The New Testament bears witness to the fact that right from the beginning some who aspired to be church leaders would be motivated by power or greed and would not be beyond lying, cheating or fiscal corruption (Mt 26:14; Jn 12, 6; Ac 5:1-11; 6:1; 8:20-23; 2 Tim 4:10). Safeguards and oversight needed to be applied and the fear of God needed to be instilled in them (Ac 5:1-11)!

\section{Practice throughout church history}

The New Testament presents a picture of financially autonomous local congregations. Whilst it seems that at times collections were made for specific congregations that were in need, such a practice was by no means the norm. This has continued to be the practice throughout most of church history. It was only in the last two centuries, under the influence of the modern business paradigm, that some denominations have opted for a centralised payment structure and even fewer opted for the equalisation of stipends.

Thus, as a reformed church that prides itself on its conformity to a New Testament pattern of church life and respects past tradition wherever possible, we must think very carefully before embarking on such a fiscal arrangement.

\section{The missional perspective}

\section{The Uniting Presbyterian Church in South Africa, a missional church}

Every denomination is missional by definition. A missional church is one where mission is the originating impulse and the organising principle of the Church, whether by intention or implication. It is a church that is being obedient to the missio Dei, in which God, as a missionary God, sends the church to fulfil his mission in the world. It explicitly includes every activity associated with social justice, social welfare, evangelism, church planting and church and Kingdom growth in general. Such a church has a missional theology that applies to the life of every constituent congregation and to every believer. Every disciple is to be an agent of the 
Kingdom of God, and every disciple is to carry the mission of God into every sphere of life. We are all missionaries sent into a non-Christian culture. The author would believe that this is the desire of the UPCSA, because its mission statement declares that one of its aims is to, 'bear witness to the saving gospel of Jesus Christ to all who do not now believe in him' (UPCSA 2009/2010:2).

Thus, the UPCSA has been called, with the accompanying stewardship responsibility, to resource missional activities in South Africa. This involves planting new congregations and helping them mature and develop until they are self sustaining and can support their own leader(s) and financially partnering with existing congregations to aid them in their missional activities.

\section{Problems with funding missional outreach}

Missional outreach, church-planting and sustaining growing congregations requires funding for the ministers involved. This has traditionally been provided in the UPCSA from a centralised fund, resourced by allocation from congregational assessments.

A blanket equalisation of stipends would reduce the necessity for such a fund. It does, however, have serious problems such as disincentivisation, increasing dependency by the resourcedreceiving congregations and an unhealthy arrogance in the resource-giving congregations.

\section{Lack of appreciation of the social complexities of disadvantaged communities}

The church is a counter-culture community and thus a catalyst for socio-economic change (Osmer 2008:192). Yet as Dames (2010) points out in his excellent article on ministering to communities with pathological socio-economic conditions, it is unhelpful for resource-giving congregations to give funds as they see fit to these communities and the congregations that serve them. This is because resource-giving congregations often have difficulty in fully appreciating the complexities and underlying assumptions of those in these disadvantaged cultures. Rather, Dames advocates collective responsibility in meeting the needs of these communities so that, 'the onus is on the community itself' (personal communication from Dames 2011).

\section{Adverse perception of support by disadvantaged communities}

Financial support for ministry in economically disadvantaged communities can, on the one hand, be perceived as paternalistic or even racist and controlling. Indeed, this may not be far from the truth. Jayakumar's (1999) research indicates that the economically rich may develop godcomplexes. They believe they have achieved their wealth through their own efforts and thus poor people are in need because of their own lamentable choices. As a result, the rich develop an unconscious feeling of superiority and suppose that they are able to make the best decisions for low-income people. It is, thus, not surprising that poverty alleviation efforts may feed the sinful god-complex within us. Simultaneously, the natural feelings of inferiority and shame that being poor induce are unintentionally reinforced. The first step for the economically rich is to realise this danger and come to the Cross and repent of their sinfulness (Corbett \& Fikkert 2009:64, 65).

\section{Development of dependency and disincentivisation}

On the other hand, funding from resource-giving congregations can also lead to dependency and a lack of responsibility amongst the poorer communities to support their local congregation or the ministry of that congregation or to grow numerically, leading to disincetivisation. This was a factor that two Presbyterian missional experiences have highlighted.

In 1843, many ministers and congregations seceded from the Presbyterian Church of Scotland to form the Free Church of Scotland, in what is known as the 'Great Disruption'. The history and economic implications of this event have been researched and summarised by Sawkins \& Mochrie (2009). Their research would suggest that disincentivisation and dependency can result from centralisation and equalisation.

The Free Church of Scotland sought to create a national network of congregations using its own resources (i.e. to be missional). They believed that their objectives could only be realised if they were able to devise a scheme for financing its activities that would draw upon the wealth of its richer adherents and channel donations through a central fund to the poorer ones.

Chalmers (one of the leading Free Church ministers) recognised 'a free-rider problem' and believed that it was important to have mechanisms in place to nurture emerging churches, but also to ensure that they understood the nature of the financial responsibilities inherent in becoming a congregation of the Free Church. He argued that the missionary nature of the Free Church was such that it would do its best work where (young) men were willing to break new ground. They should be prepared to defer the prospect of a comfortable position until they had gathered together a fair-sized congregation.

He designed a scheme whereby congregations would not be permitted to call ministers when they had given no indication of their ability to fund anything approaching a reasonable stipend. Recognising the tension that existed between aidreceiving and aid-giving congregations, Chalmers' proposal placed the burden of responsibility upon those receiving aid.

After much debate, his recommendations were mostly rejected and a scheme of support was adopted for poorer congregations whereby they were largely subsidised by more affluent congregations. A centralised stipendiary system was instituted that provided sufficient funds for congregations in disadvantaged areas to support a minister. 
When in 1900 the Free Church entered into union with the UPC, whose basis was voluntarist and whose financial structure was largely congregational, it appeared that the scheme had not produced the desired results. There are many factors that might help to explain this lack of success, such as the participation in the Church's leadership by a younger generation of ministers, who were less concerned than its founders to achieve national coverage or to challenge the rights and privileges of the established Church.

But the author of this article concludes that perhaps one contributing factor, as Chalmers foresaw, was that once the financial incentive to expand was lost many congregations settled into a rut and abdicated their responsibility to support their ministers, permanently relying upon the central fund.

This dependency and lack of responsibility amongst poorer communities that receive and come to rely upon outside financial giving to support their local congregation or the ministry of that congregation is a problem which the Presbyterian missionary, Nevius (1958:58ff), emphasised from his many years of very productive experience in classical missionary work in Korea. His book recording his experience and the methods he developed to counter this, written in 1885, is still very applicable. It may be hard to accept, but the Bible never condones poverty as a reason for not developing a self-supporting local congregation.

In fact, the apostle Paul upholds one of the poorest New Testament churches as an example to other churches of generosity and sacrificial giving:

And now, brothers, we want you to know about the grace that God has given the Macedonian churches. Out of the most severe trial, their overflowing joy and their extreme poverty welled up in rich generosity. For I testify that they gave as much as they were able, and even beyond their ability. Entirely on their own, they urgently pleaded with us for the privilege of sharing in this service to the saints. (2 Cor 8:1-4)

One would presume that such a church would have no difficulty in being self-sustaining!

Such dependency may also lead to a lack of incentive to fulfil the missio Dei and thus to a decline in evangelism and church growth. Whilst church leaders should be solely inspired by their God-given calling and vocation to do the work of the ministry, they are sinful beings, and thus are sometimes motivated by other considerations and prone to laziness, just as anybody else. The Bible is very realistic about realising that church leaders' need incentivisation (Ac 5:1-11; 8: 9-23; $2 \operatorname{Tim} 4: 10 ; 3$ Jn 1:9, 10).

As a further factor, Mead (1998:119) questions the general assumptions many churches have about outreach. He states that it his experience that they see outreach as only referring, to a congregation's obligation to provide financial assistance to those outside its walls, especially the poor or otherwise hurting'. Thus, churches often perceive what they spend on themselves as 'bad money' and what they give away as 'good money'. This is a false categorisation, because the biblical position is that everything churches do is supposed to be related to outreach. A missional congregation allows God's mission to permeate everything it does, from worship to witness to training members in discipleship (Dames 2007:35).

\section{Economic factors God's preferential option for the poor}

Low-income people face a battle to survive that produces feelings of powerlessness, worry, entrapment, oppression and hopelessness at a level that the economically secure need never experience. The materially poor are ensnared by many factors such as insufficient assets, lack of affordable medical care, poor education, neighbourhoods controlled by gangs and drug lords and characterised by high crime rates. They are often unable to make meaningful choices that will alter their situation (Sen 1999).

God's preferential option for the poor is deeply rooted in the Old Testament testimony of Israel. It is so basic that it belongs to the inalienable core testimony as to the character of Yahweh (Brueggemann 1997:144). Jesus preached the gospel to the poor and called captives into the liberty of the coming Kingdom (Moltmann 1977:78, 79). Liberation theology draws attention to the fact that the poor are the first, although not the only ones, on which God's attention focuses. Thus, the church has no choice but to demonstrate solidarity with the poor (Bosch 1991:436).

If the church appeals to the crucified and risen Christ, must it not represent this double brotherhood of Christ in itself, and be present with word and Spirit, sacrament, fellowship and all creative powers among the poor, the hungry and the captives. (Moltmann 1977:129)

Indeed it is both the church of the poor and for the poor (Bosch 1991:436).

\section{Redistribution}

The problem for any church is how to rectify this situation. One answer is through redistribution of incomes. Redistribution, at least to most South Africans, has become crucial to the allocation of wealth for many who were formerly disadvantaged, leading to the hope for increased wealth (Bähre 2006:2,11). The type of redistribution envisaged in the UPCSA through equalisation of stipends may be considered a vertical redistributive arrangement in that it would be imposed institutionally from the top down.

There is much debate from many perspectives, however, about the effectiveness of this type of redistribution. From an economic perspective Dollerya (1993) comments:

It is possible to identify two generic schools of thought on the emotive question of the racially skewed income and wealth distribution in South Africa. Some economists argue in favour of 'growth through redistribution', and postulate that redistributive policies can enhance economic growth, especially by increasing labour productivity and generating greater political stability. Others support 'redistribution through growth', and emphasise the efficiency losses attendant upon any meaningful redistribution of existing income and wealth. (p. 23ff) 
There appears to be no accepted resolution to this debate over redistribution, although convincing arguments are presented for both points of view. It thus appears that, for a church, the most important factors leading to a decision must be biblical and practical. These practical considerations, such as issues as 'post-denominationalism', the financial meltdown being experienced by mainline denominations and administrative problems, will be considered below.

\section{Postdenominationalism}

One of the challenges facing the institutional mainline churches today is post-denominationalism (Dames 2007:37). The Christendom paradigm for an institutional approach to mission is leading to an impoverishment of the financial and manpower resources of congregations, greatly hindering the actions of proclamation and service. There are numerous advantages to intercongregational denominational cooperation. Yet many denominational projects seem irrelevant to the needs congregations see on their doorsteps and thus fail to command commitment. As a result, even loyal mainstream congregations are beginning to view contributions to national denominational offices as a waste of money, rather than gifts to God (Hadaway \& Roozen 1995:101). Even if these activities are ideologically supported, they must compete with many other priorities for funding and thus local congregational outreach and church planting is insufficiently resourced (Hadaway \& Roozen 1995:99-101).

\section{Financial meltdown}

The idea that mainline congregations in developed economies are in 'financial meltdown' (i.e. that their income is rapidly diminishing) was developed by Mead (1998). It seems to apply to the UPCSA. This means that there is less money available to aid poorer congregations from the richer 'support-giving congregations'.

This is, perhaps, the most important consideration as regards equalisation. What will the cost be to the support-giving congregations? All Presbyterian Churches are expected to pay an assessment to a Central Fund, unless they receive exemption. Poorer congregations may be supported from this Central Fund if they fulfil certain criteria. Undoubtedly, the cost to the 'Central Fund' of the UPCSA, and thus the increased cost to these congregations will depend upon how much the equal stipend is set at. All the indications are that it would be considerably higher than many of these supportgiving congregations are paying at present.

This would place a considerable burden on support-giving congregations that, generally, want more autonomy over how they use the income they receive in their local areas in order to meet local needs as they believe God has directed them. It is difficult to assess how much these congregations pay at the present time in assessments to the General Assembly Central Fund and their local Presbytery. As regards the Central Fund, the amount paid is a percentage of income, structured with a sliding scale, in much the same way as income tax. It becomes even more complex when considering Presbytery assessments. A telephone survey of assessment criteria that local congregations were supposed to pay to their local Presbytery received a response from six Presbytery treasurers and revealed that local congregations are expected to pay from ZAR1 or ZAR2 per member, to $1 \%$, $2 \%, 2.5 \%$, to $5 \%$ (in the Western Cape) of income.

It is estimated that the total amount a local congregation pays in assessments to the Central Fund plus their local Presbytery may approach $18 \%$ in some cases, (the exact percentage is irrelevant but it must be of this order). Of course the wealthier a congregation is, the more that they can give without noticing it!

Moreover, it would appear that if the denomination opts for the equalisation of stipends it will move into a dangerous deficit situation. The UPCSA Accounts Department provided access to financial income against expenditure figures for the denomination from 2005 to 2008 (more recent figures were not available). It will be noticed (Table 1) that although income has increased from 2005, expenditure has outpaced it from 2007. Moreover, even with the inclusion of investments, there was a deficit in 2008. If this trend continues, it would appear that with the added burden of the costs of equalisation, investments will be rapidly depleted (in considering income growth, account must be taken of inflation and particularly the soaring rate between 2005 and 2008, which makes the income growth seem much better than it actually is or was).

Another factor that will add to this depletion, will be if assessments are raised to cope with the expected increased budget necessitated by equalisation. This may well lead some support-giving congregations to find that they have less finance to fund maintenance, growth and outreach, with a consequent membership decline which will impoverish their finances and thus lead to less assessment income for the UPCSA.

When the assessment payment profile (Table 2) of payments to General Assembly is considered it can be seen how critical this situation is. Although the chart must be by its very nature approximate, it gives a good enough idea of the situation. It only looks better in 2009 because of the massive inflation that has occurred from 2000. As of 2009 , only $11 \%$ of the congregations in effect supported the rest. This is especially serious if one considers that the majority of congregations thus supported, paid less than R10 000 per year, often much less. Then, above this, there is an extra $4 \%$ that must be paid to local Presbyteries.

TABLE 1: The Uniting Presbyterian Church of Southern Africa income versus expenditure (in Rand) 2005 to 2008.

\begin{tabular}{lllll}
\hline Year & Income & Expenditure & Investments & Surplus \\
\hline 2005 & 7149922 & 6804016 & 788398 & 345906 \\
2006 & 7486588 & 7311381 & 914466 & 175207 \\
2007 & 9486583 & 8906236 & 1324574 & 580347 \\
2008 & 9507673 & 9575266 & 780143 & (67593) \\
\hline
\end{tabular}

Note: Figures calculated from data provided by the UPCSA Accounts Department in November 2010. 
TABLE 2: Assessment to General Assembly, payment profile of Uniting Presbyterian Church of Southern Africa congregations.

\begin{tabular}{|c|c|c|c|c|c|c|c|c|c|c|}
\hline \multirow{2}{*}{$\begin{array}{l}\text { Payments per Category } \\
\text { (in Rands) }\end{array}$} & \multicolumn{10}{|c|}{ Year } \\
\hline & 2000 & 2001 & 2002 & 2003 & 2004 & 2005 & 2006 & 2007 & 2008 & 2009 \\
\hline$\geq 200000$ & 1 & 1 & 2 & 2 & 3 & 6 & 6 & 11 & 6 & 9 \\
\hline$\geq 100000$ & 8 & 11 & 9 & 9 & 11 & 8 & 9 & 7 & 12 & 12 \\
\hline$\geq 50000$ & 18 & 13 & 13 & 16 & 13 & 17 & 22 & 18 & 29 & 27 \\
\hline$\geq 25000$ & 25 & 18 & 20 & 24 & 31 & 26 & 28 & 34 & 28 & 29 \\
\hline$\geq 10000$ & 31 & 38 & 31 & 28 & 34 & 34 & 28 & 24 & 32 & 30 \\
\hline$\leq 10000$ & 104 & 117 & 134 & 131 & 156 & 116 & 113 & 92 & 86 & 103 \\
\hline$\% \leq 100000$ & 95 & 94 & 94 & 94 & 94 & 93 & 92 & 89 & 90 & 89 \\
\hline Total & 187 & 198 & 209 & 210 & 248 & 207 & 206 & 186 & 193 & 210 \\
\hline
\end{tabular}

Note: Figures calculated from data provided by the UPCSA Accounts Deparment in November 2010.

\section{Administrative problems}

This section, unlike those above, mainly concerns the practicality of running a centralised system in the UPCSA. Much thought has obviously been given to the centralisation proposals submitted at the 2010 General Assembly. They considerably advance the debate and bring the issues down to a very practical level.

However, from a practical perspective, as far as the UPCSA is concerned, perhaps the primary practical reservation is that centralisation appears to be an unnecessary duplication of administration without being able to afford the staff that is necessary to manage it. Stipend payments have to travel back and forth between local congregations, Presbyteries, the UPCSA Assembly office and the minister. Despite modern computer technology and internet banking this still leaves much room for error and dissent. At the moment, the assembly office makes errors although it only has to deal with ministers' medical aid and pension contributions. This does not presage well if these administrative responsibilities were greatly expanded and became far more complicated as it would be if the centralisation scheme were introduced. Moreover, not every Presbytery has the financial resources or capable and available manpower to manage such a system.

Past experience teaches that it may be difficult to find out from some congregational treasurers what is actually happening to the minister's stipend. Ministers themselves are under great social pressure not to 'rock the boat' and upset important members by reporting or admitting their congregation's irresponsibility when they have not been paid. The question must be asked, 'Is it good stewardship to invest in such a "multiplicative" administrative system, when it is going to be difficult to implement the sanctions and find out exactly what is happening'?

Centralisation also removes the present directness of the minister-congregation tie. Whilst some ministers would welcome this, it will probably have three negative results. Firstly, it will diminish congregational stipendiary responsibility in the long run. Secondly, it will make the denomination more important than the local congregation, which is not only unbiblical but not in the mainstream Presbyterian tradition. Lastly, it will also make it difficult for those congregations with capable and caring treasurers to implement perfectly legal but special arrangements with the minister.

Moreover, a centralised stipend payment system will require a greater number of skilled and competent administrators than are currently involved in order for it to work efficiently. This will make it a very expensive system to be supported by a small denomination with a large, economically poor constituency.

\section{Successful centralisation and equalisation schemes}

The question might be asked whether or not there are successful centralisation and equalisation schemes being run by other churches in the Reformed family. Two examples are pertinent: that of the Church of Scotland (in some senses the mother church of the UPCSA) and the Presbyterian Church of Aotearoa in New Zealand, which was investigated by the ad hoc committee on the Centralization and Equalization of Stipends prior to 2006 (UPCSA GA 2006:462ff).

The current Church of Scotland system, which has been developing for many years, is an example of a successfully managed centralised stipend system (personal communication from Graham Duncan). It must, however, be taken into consideration that Scotland is a developed country in which the Church of Scotland has many more congregations and enormous financial resources compared to that of the UPCSA. Economically, the gap between resource-giving congregations and resource-receiving congregations in Scotland is certainly far less than in the South African context, reducing the chances of a dependency syndrome developing. Scotland also has a highly educated population, with many who are financially literate and skilled at managing accounts. This makes administration of the system far easier than it would be with the UPCSA, where financial skills levels are probably equivalent to the low levels of that of the majority of the population in South Africa. Thus, the Church of Scotland cannot be a model for the UPCSA.

The Presbyterian Church of Aotearoa has two centralised stipendiary systems, one operated from the Assembly office whilst the other is operated from a synodal office for the Maori synod. Both stipendary systems set basic stipends which every minister is expected to be paid regardless of the congregation they serve. Congregations may give additional supplementary income if they so desire. The Assembly office funds the Maori synod to enable this equalisation (UPCSA GA 2006:462). The system would appear to be financially viable in New Zealand because the percentage of the economically deprived Maori population is miniscule in comparison to the economically well-resourced population, whereas in South Africa the 
deprived to well-resourced ratio stands at approximately a ratio of $40: 5$, if current estimates are accurate. Thus again, and also perhaps for some of the factors mentioned in regards with the Church of Scotland, centralisation and equalisation is not an appropriate or viable model for the UPCSA.

\section{Conclusion}

A centralised system would have too many administrative problems and be too expensive for the UPCSA and removes the directness of the traditional congregational-ministerial bond, which has the biblical and ecclesiological underpinning preferred by a Reformed denomination. Church history, ecclesiology, missiology, biblical anthropology and sociology suggest that the equalisation of stipends will lead to disincentivisation of both congregations and ministers. It will perpetuate a dependency syndrome amongst the receiving congregations and a 'god-complex' amongst the supportgiving congregations. In fact, it dooms poor communities to remain forever poor. Church members will be robbed of the joy of sacrificial giving that comes when they assume responsibility to support their local congregations. Moreover, the present financial meltdown experienced by the UPCSA and the current climate of post-denominationalism may make it very difficult to sell the idea to many resource-giving congregations.

\section{Recommendations}

If redistribution of resources and equalisation of stipends is not the answer, what is?

There is no doubt that in order to fulfil our social obligations and missional mandate from the risen Lord, the UPCSA must seek to plant new congregations and continue to support existing healthy ones. One factor in achieving this is that we must help congregations increase ministers' stipends in the economically poorer communities.

Any system of centralised redistribution will fail, however, if there is a suspicion that the congregation is being patronising, producing dependency, decreasing the pastoral tie, and not having both a biblical basis and the support of historical tradition. This failure might well have serious and unnecessary economic consequences for both the UPCSA and supportgiving congregations, leading to lack of resources for mission.

It is suggested that the first step in dealing with this problem of lack of funding is for the church to fulfil its missional mandate by accepting that the Bible teaches that God's plan for stewardship is to produce abundance. He has planted human resources in every community to enable Christians to break out of the vicious cycle of poverty, hopelessness and dependence on donor funding into the abundance he has appointed for them.

Along with such a step of faith is the requirement that the local congregation exercise stewardship faithfully, wisely and industriously. Many efforts have been made in the past to produce this at the level of the local congregation and to try and raise the levels of giving through stewardship teaching and campaigns. The results have been magnificent in some congregations, but have obviously failed in many others.

Teaching alone does not work. Individuals, communities and churches need to surrender to God. Only an experience of the work of Jesus completed on the Cross can free us to make the right stewardship choices. And only God, the Holy Spirit, received at the new birth can empower us to enact these choices. Only then will men and women receive the grace to rejoice in their unique callings.

It is suggested that ministers' training emphasise stewardship, calling, the Cross and the resurrection. Ministers will become fully committed when they believe that they have a calling from God to the economically unique congregations that they serve. Congregations will only be prepared to support their ministers to the full when they have experienced the same renewing work of grace that God did amongst the povertystricken Macedonian congregations. Rich churches will only die to their God-complexes, and receiving congregations to their dependencies, when they come to the Cross and live in the power of the resurrection of Jesus.

Ultimately, whatever steps need to be taken, the 'financial meltdown' and financial resourcing problems faced by the UPCSA reflect a spiritual problem. These problems seem to indicate that the Cross and the resurrection are not central in the church's life. The focus is not on Jesus and being a church for others. What are we to do? It is God who builds his church (Ps 127:1-3). Only God can change hearts (Ezk 36:26). We need to seek him in repentance and call out for him to change hearts and bring revival.

At the same time we need to examine how we train our ministers. In our money-centred world, knowledge of a biblical theology of stewardship is essential. Ministers then need to be equipped to communicate that knowledge to the 'oral' non-literate society to which many are called in the face of entrenched umbilical cultural practices and attitudes (Snowdon 2012:2). Only then will communities and churches be empowered to discover and utilise the resources God has planted within them. These latter suggestions would seem to be the optimum solution for our denomination. Much recent literature of a very practical nature has also recently emerged, stemming from many years of experience in Africa, of how partnerships may help to rectify the situation without incurring either perceptions of being patronising or hindrance to spiritual growth through dependency. In fact, such an approach can lead to a building up of selfesteem and commitment to the Kingdom of God in poorer communities. Then they will become faithful stewards of the rich resources that God has given them and the beginning of a new abundance will result, both in terms of spiritual life and financial provision. (For further information see Corbett \& Fikkert [2009], who also have an excellent bibliography.) 
This is God's world and the church is not bringing Christ to poor communities. He has been active in these communities from the beginning of the world. Thus, a significant part of working in poor communities includes discovering what God has been doing there for a long time and then facilitating its use. Support-giving congregations are not superior, but have much to learn from them (Corbett \& Fikkert 2009:129ff)!

\section{Acknowledgements Competing interests}

The author declares that he has no financial or personal relationship(s) which may have inappropriately influenced him in writing this paper.

\section{References}

Atkinson, J., 1988, 'Vocation', in S. Ferguson \& D. Wright (eds.), New Dictionary of Theology, p. 711, Inter-Varsity Press, Leicester.

Bantu Presbyterian Church of South Africa, 1925, Minutes of 1924-1925 Genera Assembly, South Africa.

Bähre E., 2006, 'New sources of wealth, new sources of conflict: A historical approach to burial societies and insurance among the Xhosa in South Africa', paper presented at the 2006 ASSA convention, Cape Town, October 12-13, 2006, n.p.

Bonhoeffer D., 1959, The Cost of Discipleship, SCM Press Ltd., London.

Bosch, D., 1991, Transforming Mission, Orbis Books, New York.

Brueggemann, W., 1997, Theology of the Old Testament, Fortress Press, Minneapolis. Chafin, K., n.d., '2 Corinthians', in The Preachers Commentary, L. Ogilvie (ed.), viewed n.d., from www.biblesupport.com

Corbett S. \& Fikkert B., 2009, When helping hurts, Moody Publishers, Chicago.

Dames, G., 2007, 'New Frontiers for mission in a post-modern era: Creating missional communities', Missionalia 35(1), 34-53.

Dames, G., 2010, 'The dilemma of traditional and 21st Century pastoral ministry: Ministering to families and communities faced with socio-economic pathologies', HTS Teologiese Studies/Theological Studies 66(2). http://dx.doi.org/10.4102/hts. v66i2.817

Davies, W. \& Allison, D., 1997, 'A Critical and Exegetical Commentary on the Gospel according to Matthew', in The International Critical Commentary, Matthew XIXXXVIII, vol. 3, T\&T Clarke, Edinburgh.

Dayton, H., 2006, Your Money Counts, Crown Financial Ministries Inc., Paarl. http:// dx.doi.org/10.1016/j.explore.2006.05.003

Dodd C., 1932, The Epistle of Paul to the Romans, Moffat NT Commentary, Hodder and Stoughton, London.

Dollerya B., 1993, 'Redistribution: A conceptual framework for the growth and redistribution debate in South Africa', Development Southern Africa 10(1), 23-31. http://dx.doi.org/10.1080/03768359308439664

Grenz S, 2005, 'The social God and the relational Self: Toward a trinitarian theology of the Imago Dei', in L. Metzger (ed.), Trinitarian Soundings in systematic Theology pp. 87-100, T \& T Clark, Edinburgh.

Fitzmeyer, J., 1993, Romans The Anchor Bible, Doubleday, New York.

Hadaway, C. \& Roozen, D., 1995, Rerouting the Protestant Mainstream, Abingdon Press, Nashville.

Harnack, A., 1908, The mission and expansion of Christianity in the first three centuries, transl. and ed. J. Moffatt, Christian Classics Ethereal Library, Grand Rapids, MI.

Herron, A., 1993, 'Stipend', in N. Cameron, D. Wright, D. Lachman, D. Meek (eds.) Dictionary of Scottish Church History \& Theology, T \& T Clark Ltd., Edinburgh.

Jayakumar C., 1999, 'Powerlessness of the poor: Toward an alternative kingdom of God based paradigm of response', Ph.D thesis, Fuller Theological Seminary, Pasadena, California.

Jewett, R., 2007, Romans, Fortress Press, Minneapolis.

Leith, J.H., 1992, 'The Ethos of the Reformed Tradition' in D.K. McKim (ed.), Major Themes in the Reformed Tradition, n.p., Wm. B. Eerdmans Publishing Co., Grand Rapids.
Martin, R., 1986, 2 Corinthians, Word Biblical Commentary, D. Hubbard, G. Barker, R. Martin (eds.), Word Incorporated Books, Dallas, Texas.

McLaren, B., 2004, A generous orthodoxy, Zondervan, Grand Rapids, MI.

M'Grath, A., 2007, Christian theology, An introduction, Blackwell Publishing, University of Oxford.

Mead, L., 1998, Financial meltdown in the mainline, Alban Institute, New York.

Moltmann, J., 1977, The church in the power of the Spirit, SCM Press, London.

Moo, D., 1996, 'The Epistle to the Romans', The New International Commentary of the New Testament, William B. Eerdmans Publishing Company, Grand Rapids, MI.

Morris, L., 1988, 'The Epistle to the Romans', The New International Commentary of the New Testament, William B. Eerdmans Publishing Company, Grand Rapids, ML.

Nevius, J., 1958, Planting and development of missionary churches, The Presbyterian and Reformed Publishing Company, Phillipsburg, NJ.

Nolland, J., 1993, 'The use and abuse of riches, Luke 16:1-31', in D. Hubbard, G. Barker \& R. Martin (eds.), Word Biblical Commentary Luke 9:21-18:34, pp. 792-827, Word Incorporated Books, Dallas, Texas.

Osmer, R., 2008, Practical theology: An introduction, William B. Eerdmans Publishing Co., Grand Rapids.

Pieterse, H., 2001, 'Sermon preparation in context', Practical Theology in South Africa 16(2).

Plummer, A., 1911, 'Second Epistle of Paul to the Corinthians', in S. Driver, A. Plummer, C. Briggs (eds.), The International Critical Commentary of the Old and New Testaments, n.p., T\&T Clark, Edinburgh

Plummer, A., 1915, 'Second Epistle of Paul to the Corinthians', in S. Driver, A. Plummer \& C. Briggs (eds.), The International Critical Commentary of the Old and New Testaments, n.p., T\&T Clark, Edinburgh.

Reformed Church in Southern Africa, 1980, Proceedings of the Fifty-Seventh General Assembly, Lovedale Press, Lovedale, South Africa

Sen A., 1999, Development as freedom, Anchor books, New York.

Sawkins J. \& Mochrie R., 2009, The use of economics of religion in the Free Church of Scotland, 1843-1870, Department of Economics, Heriot-Watt University, Edinburgh.

Snowdon, M., 2012, 'Are we training our pastors wrong? Or how can we train pastors more effectively?', viewed April 2012 from, http://conversation.lausanne.org/en/ resources/detail

Thrall, M., 1996, 'A critical and exegetical commentary on the second epistle to the Corinthians', in J. Emerton, C. Cranfield \& G. Stanton (eds.), The International Critical Commentary II, T\&T Clark, Edinburgh.

Uniting Presbyterian Church in Southern Africa, 2006, Proceedings for 7th Genera Assembly 2006, Uniting Presbyterian Church in Southern Africa, Johannesburg, South Africa.

Uniting Presbyterian Church in Southern Africa, Directory 2009/2010, Uniting Presbyterian Church in Southern Africa, Johannesburg, South Africa.

Uniting Presbyterian Church in Southern Africa, 2009, Annual Financial Statements for Year Ended 31 December 2009, Uniting Presbyterian Church in Southern Africa, Johannesburg, South Africa.

Uniting Presbyterian Church in Southern Africa, 2010, Proceedings and Decisions for 9th General Assembly, Vereenigeng, Presbytery of Lekoa, 25 Sept. - 01 July 2010, Uniting Presbyterian Church in Southern Africa, Johannesburg, South Africa.

Uniting Presbyterian Church in Southern Africa, 2011, Proceedings and Decisions of the 9th General Assembly, Uniting Presbyterian Church in Southern Africa, Johannesburg, South Africa.

Uniting Presbyterian Church in Southern Africa, 2011, Decisions of August 2011 Executive Committee, Uniting Presbyterian Church South Africa, Johannesburg, South Africa.

Vanhoozer K., 1997, 'Human being: Individual and social', in C. Gunton (ed.), The Cambridge Companion to Christian Doctrine, pp. 158-188, Cambridge University Press, Cambridge.

Venter, R., 2011, Speaking God today: The adventures of a rediscovered trinitarian grammar, SUN MeDIA, Bloemfontein. http://dx.doi.org/10.1017/ CCOL0521471184.011

Webster, J., 2003, 'The human person' in K. Vanhoozer (ed.), The Cambridge Companion to Postmodern Theology, pp. 219-234, Cambridge University Press, Cambridge. http://dx.doi.org/10.1017/CCOL052179062X.013

Willingale, A., 1982, 'Debt', in J. Douglas (ed.), New Bible Dictionary, 2nd edn., pp. 275-276, Inter-Varsity Press, Leicester.

Zerfass, R., 1974 'Praktische Theologie als Handlungswissenschaf', F. Klostenmann (Hg.), Praktische Theologie Heute, Kaiser Grünewald, München. 